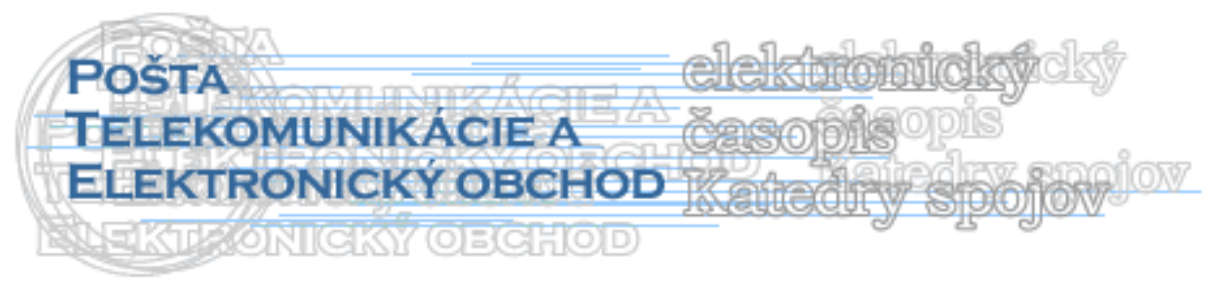

\title{
COURIER, EXPRESS AND PARCEL SERVICES IN THE NEW CONDITIONS
}

\author{
Libor Svadlenka*
}

\section{Introduction}

Although the term CEP (courier, express and postal service) has been already used for a relatively long time, it seems to be still uncertain which subjects come under this market and also how to set boundaries to this market. Consequently it is useful to define single segments of this market at first.

\section{Courier service}

The title of this segment is derived from the courier person. Courier service involves individual collection of the item, permanent individual personal escort during the transport of the item and personal delivery of the item. Courier service is realized especially in urban area (e. g. Messenger company with its service Cityexpress), however also in regional, national (e. g. Messenger company with its service Intercity) and international area. Various operation areas mean various used means of transport - bicycle, motorcycle, car, van and also partially various transported things - from documents to pallets. Especially in international area the primary form of the courier service was replaced with transportation with application of so called pickup service (e. g. DHL, TNT, UPS etc.). However these companies come under express not courier segment because of standard conditions of their services.

\section{Express service}

To this segment belong all the companies, which transport items exclusively, indirect through the tranship points to the destination with personal escort of the items during the transport. Transported items are distributed through the system management in collecting transportation and delivered after arrangement of usually guaranteed delivery time (e. g. till 9:00 hours or 12:00 hours next working day). As opposed to forwarder's offers there is a fixed delivery time - from house to house. There isn`t possibility to define this segment by weight and size definition of transported item, for the express service realizes transportation of whatever items (in relation to size and weight). Classification confusion increase in addition itself express companies, because sometimes they call their services "courier services", although they don't ensure personal individual escort of transported items.

There is a possibility to define so called express freight system as a partial segment of express service. This partial segment emerged from assumption of just-in-time mechanism to express area. Suppliers are mostly forwarders or similar companies which are specialized in distributing of certain goods (e. g. drugs, cosmetics etc.) Transportation is realized in large

\footnotetext{
* Ing. Libor Švadlenka, Ph.D., Department of Transport Management, Marketing and Logistics, Jan Perner Transport Faculty, University of Pardubice, Studentská 95, 53210 Pardubice, Czech Republic, tel.: +420466036375, fax: +420466036374

e-mail: Libor.Svadlenka@upce.cz
} 
quantity in standardized or size-limited containers. Next attribute is a large-scale integration to customer's company flows. Transported item is for example accepted directly in the production and then through the complex net of line services the item is transported within fixed timetable.

\section{Parcel service}

In connection with the CEP definition it is imperative to understand this segment as an express service subsegment. Typical attribute is standardization of transported items with regard to automatic sorting, which enables their quick transportation. So size and weight of transported items are limited by concrete values (e. g. for Czech Post service business parcel maximum weight is $30 \mathrm{~kg}$, none of dimension must exceed $240 \mathrm{~cm}$, sum of length, width and height of the item with regular shape must not exceed $300 \mathrm{~cm}$ and the minimum dimension of this item must be $15 \mathrm{~cm} \times 10,5 \mathrm{~cm})$. As opposed to the express service the course of transportation is not guaranteed, it is only respected with high probability.

\section{Postal service}

Although Act no. 29/2000 Sb., on postal services and amendment to certain Acts defines postal service as , an activity performed on the basis of a postal contract, according to terms laid down by this Act, for the purpose of delivering a postal item or remitted money amount", 1 where postal items are „, items of correspondence or other matters which have been taken over as a single unit by the postal service operator for the purpose of providing postal service "2 it is necessary to understand the postal service as a service consisting of collection, sorting, transportation and delivery especially lightweighted items. Externally homogenous delivery process is possible to further specify according to different logistic requirements on individual items (items of correspondence, news, magazines, catalogues etc.). Free providing of postal services is still restricted, although miles less than in past, by existing "postal monopolies" of national postal operators (e. g. the Czech Post in the Czech Republic), which ensure them privileged position in transportation of items within fixed weight and price limits.

\section{Significance of the CEP}

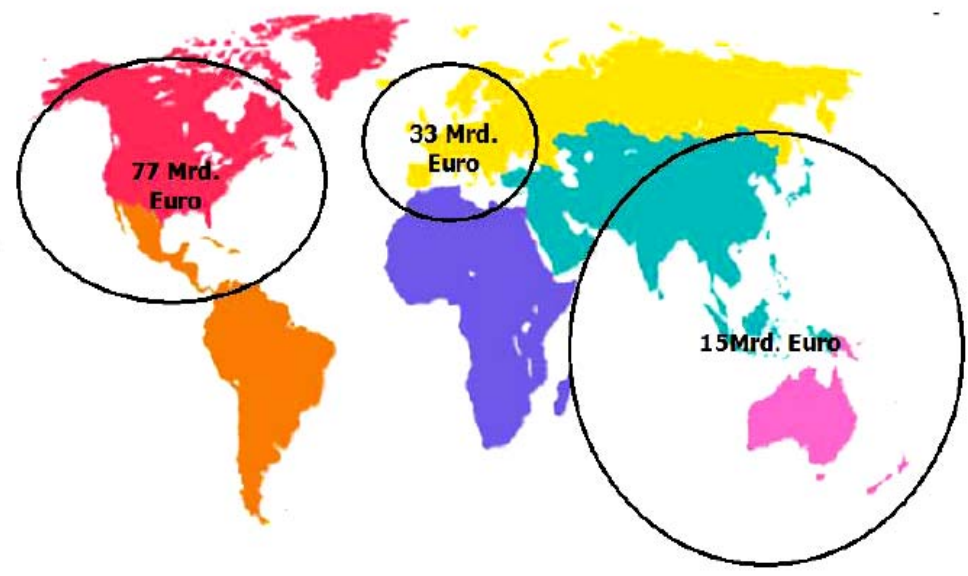

Fig. 1 The most important world markets

CEP market come under a strongly increasing markets especially in recent years.

\footnotetext{
1 § 1, odst. 2, zákona č. 29/2000 Sb., o poštovních službách a o změně některých zákonů

2 § 2, písmeno a) zákona č. 29/2000 Sb., o poštovních službách a o změně některých zákonů
} 
Fig. 1 describes the most important world markets, which also fall into a crucial expansional targets of most CEP companies. In Europe the most important markets are Germany, France and Great Britain which concentrate nearly three quarters of total CEP market turnover. follows.

German CEP market as one of the most important CEP markets is developing as

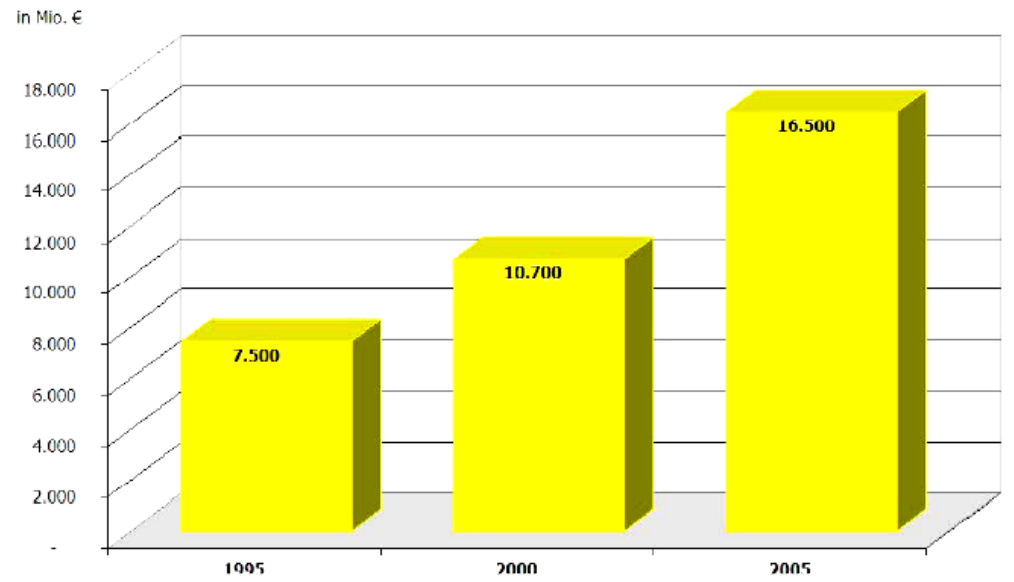

Fig. 2 Development of the German CEP market turnover in years 1995-2005

Source: MRU GmbH.

\section{Impact of EU accession on the Czech Republic CEP market}

On May the first 2004 ten new members ${ }^{3}$ joined the EU, which means that the number of EU inhabitants increased by 75 millions and the area increased by $34 \%$.

From the point of view of CEP market were in connection with the EU accession important especially changes relating with movement of goods among EU states and the other states:

- Items come from the EU member state

$>$ free movement of goods,

$>$ without customs clearance,

$>$ free of customs supervision,

$>$ INTRASTAT

- Items from the third states

$>$ customs clearance,

$>$ TARIC\&electronic customs proceedings,

$>$ NCTS - New Computerized Transit System (T1),

$>$ FPE - first point entry (low value shipments).

Further positive effects of EU accession, such as unification of financial system (because of newly applied common tax procedures), new market possibilities, economies of scale, facilitation of foreign partners access to domestic companies and so on are taken for granted.

\section{Express carriers reaction}

EU accession and customs control withdrawal implied the new and more quality services which express carriers could offer.

\footnotetext{
${ }^{3}$ Cyprus, Czech Republic, Estonia, Hungary, Lithuania, Latvia, Malta, Poland, Slovenia, Slovakia
} 
For example DHL company offered to customers new service called European Community Express with its products:

- European Community Express - it brings to customer simple solution at sending documents and goods items to EU states, because the customer already needn't think of the fact, whether the item is document or goods and it is transported to whatever EU state for the flat rate till next working day,

- StartDay Express - it makes possible deliver express item till 9:00 h. next working day to whatever EU state. In case of delivery time overrun, the company refunds part of the transport costs,

- MidDay Express - it makes possible deliver time sensitive item till 12:00 h. next working day to whatever EU state. In case of delivery time overrun, the company also refunds part of the transport costs.

Of course other companies acting in this field offered very similar services, for example TNT - 9:00 Express and 12:00 Express with guaranty of repayment the total amount in case of later delivery or UPS - UPS Express plus (till 9:00 h. next working day), UPS Express (till 12:00 h. next working day) UPS Express Saver (till next working day) with guaranty of repayment of the total amount in case of later delivery. The Czech Post has a different attitude with its express service EMS. The guaranty of certain delivery time is difficult, because the transportation is realized by several national postal operators. That is the reason why the Czech Post guarantee delivery time only to arrival to state of destination. Of course the price for this service is much smaller than prices for foregoing services like StartDay Express etc. of competitive express companies. EU accession means simplification for this service, because there is no need to clear the items or fill out the bill of entry for postal items within EU.

Generally the portfolio of services, which offer express companies in the Czech Republic is broadly the same as in other EU states, which is consequence of partly globalisation and partly internalization of supranational companies.

\section{The future of CEP market}

The express industry is likely to remain one of Europe's fastest-growing sectors. The requirement for rapid delivery is likely to intensify further among existing users of the express industry and spread to other sectors of the economy as, for example, more businesses use the internet for purchasing and supply management, and the demand for logistics services increases. Moreover, international trade is expected to continue to grow rapidly - $\mathrm{OEF}^{4}$ forecasts it to increase by over $90 \%$ over the next decade compared with a rise of almost $40 \%$ in world GDP.

Neither European nor Czech companies generally expect that new technological developments and distribution methods (e.g. transferring information, data or contracts by secure electronic means such as secure web-based products and broadband data transmission) will reduce their use of express services.

OEF expect the express industry to grow by an average of $9 \%$ a year in real terms between 2003 and 2013. This is around four times faster than OEF forecast of 2,5\% a year real growth for the EU economy as a whole over the next decade.

\footnotetext{
${ }^{4}$ Oxford Economic Forecasting Ltd.
} 
Tab. 1 Prospects for the express industry over the next decade

\begin{tabular}{|l|c|c|}
\hline & $\begin{array}{c}\text { Per annum growth } \\
1998-2003\end{array}$ & $\begin{array}{c}\text { Per annum growth } \\
2003-2013\end{array}$ \\
\hline World trade & 6 & 7 \\
\hline Express industry output & 12 & 9 \\
\hline EU 25 real GDP & 2 & 2,5 \\
\hline
\end{tabular}

One area where express services are likely to be particularly critical to the EU's and Czech Republic's success is the knowledge-based sectors, such as pharmaceuticals/biotechnology, financial and business services, research \& development, and the 'high-tech' industries (e. g. information technology equipment and services, internet business).

It is evident that firms in the knowledge-based sectors are more-than-usually dependent on express services, reflecting the kind of products and services they provide, such as:

- High-value items, for which low stocks are essential (electronic components etc).

- Perishable items (such as tissue or blood samples for clinical trials).

- Failed items, such as personal computers, for which rapid repair and return is essential.

- Items purchased on-line, where rapid delivery to the customer is essential.

High-tech manufacturing companies can rely on express services in the following ways:

- Just-in-time stock management. By allowing rapid (often same-day), reliable delivery, both of sub-components and spare parts on the one hand, and products to customers on the other, express services are a vital ingredient in keeping stock levels low. That is particularly important for these firms, whose products are typically high in value and have a relatively fast depreciation rate. Holding inventory of such products is very costly.

- Concentration in one location. Two interviewees reported recent closure of branches in other countries and consolidation in parent state that would not have been possible without express services.

- Shipment of time-sensitive goods. Customers often require replacement parts for failed items the day after the breakdown occurs, and express delivery allows the high-tech companies to guarantee this. Rapid, reliable delivery is essential to the reputation of these firms, and they are able to charge a premium price for this premium service.

- Global sourcing / global reach. Express services allow high-tech firms to take advantage of the benefits of global sourcing, and to access markets for their products all over the world - still guaranteeing next-day delivery in most cases.

\section{Conclusion}

Despite above mentioned, using of express services in the Czech Republic is still in compare with developed EU states relatively low. $63 \%$ of medium-size and big Czech companies offering services don't use express parcel services so far. This fact hobbles competitiveness of Czech companies and decreases their chance to successfully penetrate the EU market.

The experience of DPD shows that using of express parcel services is directly connected with economic prosperity. For example in Germany $94 \%$ of companies use these services while in the Czech Republic only $37 \%$ companies and in Slovakia $29 \%$ companies. 
In addition the research realized by Brand in July 2002 showed that only $8 \%$ of express items are sent abroad. It is obvious that Czech companies have a long journey before them and consequently it seems to be a great time for Czech CEP market.

Note: The paper is published within solution of research proposal VZMSM0021627505 "The transport systems theory"

\section{References}

1. CEMPÍREK, V. Courier, express and parcel services. Logistics, 2005, n. 3., p. 36-37.(in Czech)

2. The Economic Impact of Express Carriers in Europe. [online]. Oxford Economic forecasting 2004. [cit. 2005-02-01]. Available from: <http://www.euroexpress.org/oefen>.

3. ŠVADLENKA,L., HODÁKOVÁ, M. More quality services offer. Logistics, 2005, n. 3, p. 40-41. (in Czech)

4. Express services. [online]. 2005 [cite 2005-04-20]. Available from: $<$ http://www.dhl.com/publish/g0/en/services/exp_services.high.html $>$.

5. Express services. [online]. 2003 [cite 2005-04-20]. Available from: $<\mathrm{http}: / /$ www.tnt.com/country/en_generic/services.html $>$.

6. Express services. [online]. 2005 [cite 2005-04-21]. Available from: $<$ http://www.cpost.cz/jetspeed/?js_language $=$ en $>$.

\section{Resümee}

Der Beitrag befasst sich mit dem Sektor der Kurier-, Express- und Postdienste. Er definiert Begriffe, beschreibt seine Bedeutung, geht die Auswirkung des Beitritts der Tschechischen Republik zur Europäischen Union auf diesen Sektor nach, bzw. auf seine Beteiligten, und schätzt seine Entwicklung künftighin ein. Er unterstreicht vor allem die Sektoren, die auf den Kenntnissen und ihrem Anschluss an den Expressdienstssektor aufgebaut sind, und sieht die versprechende Zukunft dieses Sektors voraus. 